\title{
Impact of Zoning and Archaeological Legislation on Land Values in Kandy Municipal Council Area: A Hedonic-type Analysis
}

\author{
R.M.H. Rathnayaka ${ }^{1}$ and D.V.P. Prasada ${ }^{2 *}$ \\ ${ }_{1}^{1}$ Postgraduate Institute of Agriculture, University of Peradeniya, Peradeniya, Sri Lanka \\ ${ }^{2}$ Department of Agricultural Economics and Business Management, Faculty of Agriculture, University of Peradeniya, \\ Peradeniya, Sri Lanka
}

\section{ARTICLE INFO}

\section{Article history:}

Received: 13 August 2019

Accepted: 30 October 2019

Revised version received: 02 June 2020

Available online: 01 July 2020

\section{Keywords:}

Land values

Zoning law

Archaeological regulations

Kandy

Hedonic models

\section{Citation:}

Rathnayaka, R.M.H. and Prasada, D.V.P.

(2020). Impact of Zoning and

Archaeological Legislation on Land Values in Kandy Municipal Council Area: A

Hedonic-type Analysis. Tropical

Agricultural Research, 31(3): 48-59.

DOI: http://doi.org/10.4038/tar.v31i3.8396

\begin{abstract}
Land values are important considerations for land use and development planning. Using data on land values recorded at the Government Valuation Department (Central regional office), this study investigated factors affecting land values of Kandy municipal area for the period 1980 to 2015, with a particular focus on testing the impact of zoning and archaeological regulations on land value. To derive inferences, we estimated hedonic-type models, which is a standard technique for analysis of land and property values, on a sample of 169 randomly selected land parcels in Kandy municipal area. Among the key findings, we observed that the impact of urban development zoning law on the value per perch was LKR 1,085,075 while the impact of archeo02logical regulation on the value was LKR 322,420 per perch within the municipal limits. Both zoning regulations and carpet road access created robustly positive impacts on land values, across several specifications including a model that included land values adjusted for inflation.
\end{abstract}

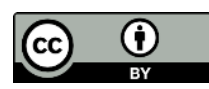

*Corresponding author : pp16252@gmail.com 


\section{INTRODUCTION}

Land is a vital natural resource for livelihoods. It is the resource which assimilates all other natural resources within it and provides the basis for meeting all human, biological and environmental needs. Land value is an important factor in planning, development and land use conversion decisions. A key economic aspect attributed to land is its wealth-equivalence. For these and other reasons, land valuation is an important consideration in land management.

Land value is an essential aspect of property markets worldwide and is determined by a variety of factors. Various studies have examined factors affecting land values as locational attributes, physical properties, neighbourhood characteristics, environmental attributes, and land use regulations. These include review studies (Ihlanfeldt, 2007; Cheshire and Vermeulen, 2009) as well as empirical analyses focusing on specific cities (Okokor, 2005; Jimoh and Ige, 2017).

Nicholls (2004) provided a classification of factors affecting property values as follows: a) Structural attributes e.g. lot size b) Neighbourhood attributes e.g. socio-economic characteristics of neighbourhood, quality of neighbouring structures, ownership/rental, and ethnic composition of neighbourhood c) Community attributes e.g. school and administrative districts d) Locational attributes e.g. proximity and accessibility to various (dis)amenities including waste sites, power lines, highways, commercial centres, schools, cultural opportunities, transportation hubs e) Environmental attributes e.g. view from property, noise levels, pollution levels, storm water accumulation, and f) Timerelated attributes e.g. month and year of sale, number of days on market.

According to Kolowe (2014), the factors influencing urban land price are access to amenities such as water, and indicators of social and economic infrastructure. ElBarmelgy et al. (2014) also classified the variables that affect land use and land value were classified into geographic, environmental, economic, social, urban, public interest, laws and legislation, demographic, political variables. Further evidence is generated by Kok et al. (2014) who grouped the variables determining property values into environmental variables, neighbourhood variables, accessibility (location) variables.

Cheshire and Shepard (1995) concluded that intra-urban variations along topographic, economic, and demographic dimensions are important determinants of land prices. They found that topography (e.g. hilliness, elevation, earthquake fault lines, etc.) has a significant influence on land prices.

Closer to our research question, several studies estimate the impact of regulations on land value. Quigley and Rosenthal (2005) investigated the determinants of urban land prices in terms of land use regulations, spatial patterns of physical development and occupancy, the housing and transport costs of residents, and their economic well-being. Jaeger (2006) highlighted that the effect of a land-use regulation on property values can be positive or negative, whereas removing a landuse regulation from one property can be expected to have a positive effect. Indeed, many land use regulations actually increase property values by creating positive "amenity effects" and "scarcity effects." Because of these differences, a positive estimate for removing a land-use regulation on value cannot be interpreted as proof of pressure of regulations on land values.

The possibility of regulations increasing the land value is real in many contexts (McMillen and McDonald, 1993). Specific studies focusing on zoning have generated evidence of land value changes due to zoning regulations (Asabere and Colwell, 1984). Often, there is a mistaken public sentiment that land-use regulations tend to reduce property values. Evidence discussed above suggests that it is not necessarily true. Our approach was an extension to the studies that investigated the implications of regulations. We analyzed the link between the regulations, physical access of sites, the topography and the prices of land, both nominal and real.

Land value is one of the essential factors influencing the pattern of urban development. Government uses land use planning to manage the development of urban areas within their jurisdictions. The subject of physical planning 
is devolved to the local authorities in Sri Lanka. Urban Development Authority Law No. 41 of 1978 is an important planning legislation enacted in Sri Lanka regarding urban lands, and it is the most powerful planning regulation used in Sri Lanka. The above Law was enacted to promote integrated planning and implementation of economic, social and physical development in declared areas of the country. According to this legislation, when a location is identified for a special development purpose, by order published in the Gazette, such area is declared as an Urban Development Area under the section 3 of the law.

Once declared, Urban Development Authority of Sri Lanka (UDA) is delegated all authority for planning and development within that area. Under this legislative coverage, the Development Plan for Urban Development Area of Kandy became a legal document with effect from 27th April, 2002 (GoSL, 2001). Therefore, any development within the development area of Kandy should be in conformity with the provisions of this development plan and any other relevant enactment. The development plan of 2002 specified three classes of regulations: zoning regulations, planning regulations and building regulations (Urban Development Authority, 2002).

Given the above context, the main objective of this study was to identify the effects of Urban Development Authority Law on land values in Kandy municipal council area through identification of factors affecting land values and their incremental contribution to unit value of land.

\section{MATERIALS AND METHODS}

\section{Study Area}

Kandy is second only to Colombo as the administrative centrality in Sri Lanka. It is the second-largest city of the island and capital of Central province of the country.

The city of Kandy or Urban Development Area of Kandy has been a major cultural, commercial, administrative and transport centre since its establishment as the capital of Kandyan kingdom in the 15 th century AD.

\section{Data Sources and Methods of Data Collection}

This study used secondary data collected from Government Valuation Department (Central regional office) of Sri Lanka. Land values have been collected through field survey by the Department within Kandy Municipal council area.

Other sources of information included the Development plan for Urban Development Area of Kandy, Urban Development Authority, Kandy Municipal Council and Road Development Authority. Based on these sources, the panel dataset was constructed by authors for the period 1980 to 2015 covering 169 randomly selected lots of land. Generally, land values do not change rapidly every year in the market and lease rent of leased properties are revised every five years according to the land manual in Sri Lanka. Therefore, this study considered land values at five year intervals from 1980.

\section{Sampling Framework}

A stratified random sampling procedure was used to select the sample based on number of commercial and residential sites located in KMC area and the spread of the sites within the area. Accordingly, 75 commercial land lots and 94 residential land lots were considered in this study and variables relevant to these parcels including the recorded valuations were collected for the period from 1980 to 2015 in KMC area.

\section{Analytical Framework and Methods}

This study employed the Hedonic pricing model to analyze the determinants of urban land values in Kandy Municipal Council area of Sri Lanka. Data collected for this study was also used to understand trends in urban land values using time trend analysis. Data entry and analysis was done using Version 14 of the Software Package for Social Sciences (SPSS). 


\section{Land Value Locations in KMC area}
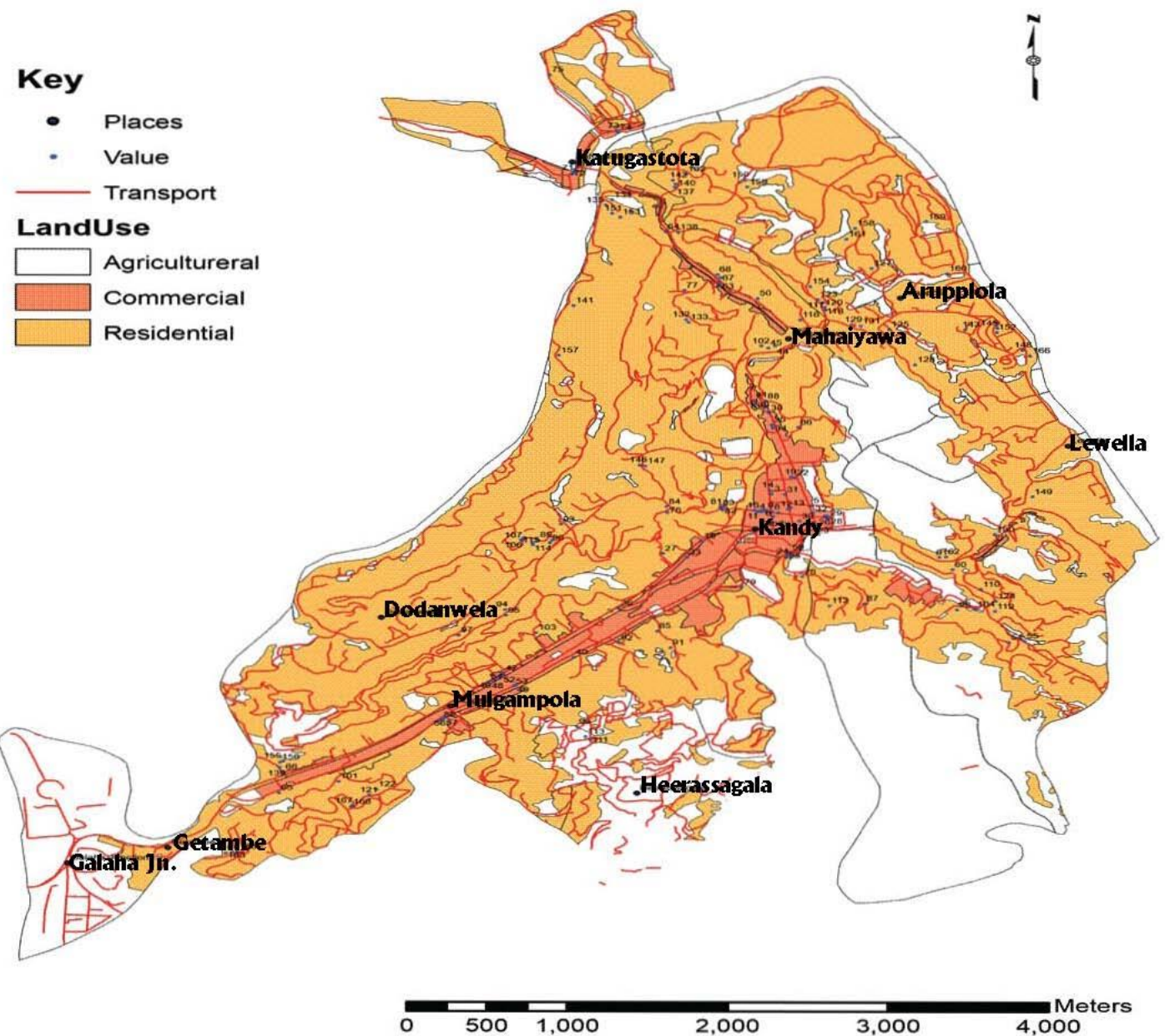

Figure 1. Locations considered for the study

Conceptually, the Hedonic model is an asset pricing method that explains the land or built property value as a function of its attributes, which include structural, neighbourhood, location and environmental characteristics. The Hedonic pricing model assumes the following general specification:

$$
P_{i}=f\left(S_{i}, N i, R i\right)
$$

$\boldsymbol{P} \boldsymbol{i}$ denotes the price of the asset i (which, in our case, is the land value per perch) as a function of structural attributes measured by vector $\boldsymbol{S i}$ (location, size of the land, shape, access etc.), characteristics of the neighbourhood where the property is located defined by vector $\boldsymbol{N i}$ (access to amenities and public services) and regulation attributes represented by vector $\boldsymbol{R i}$ (zoning law and archeological regulations).

We used four alternative specifications, including a 'benchmark' model and two stepwise regression specifications. Last specification was a model estimating the inflation-corrected land value based on the better fitting model between specification 2 and 3 . 
Model 01:

Nominal value $=f($ distance to city center, zoning law, archeological law $)$

This was the benchmark model. The model explained the variation of nominal land prices using the location classifiers and the applicability of the zoning law and archaeological law. The location classifiers were included in the form of binary variables as follows: $\ln 1$ = Location Within 0-1 km from town centre; $\ln 2$ = Location Within 1-2 km from town centre; $\ln 3=$ Location Within 2-3 $\mathrm{km}$ from town centre; $\ln 4=$ Location Within 3$4 \mathrm{~km}$ from town centre; $\ln 5=$ Location Within $4-5 \mathrm{~km}$ from town centre; $\ln 6=$ Location Within 5-6 km from town centre; $\ln 7=$ Location Within 6-7km from town centre

\section{Model 02:}

Nominal value $=f\left(\begin{array}{c}\text { Distance to city center, zoning law, archeological law, physical condition } \\ (\text { flat }, \text { sloping, steep), } \\ \text { Shape (regular, irregular, triangular })\end{array}\right)$

The second estimation supplemented the base model with physical parameters of the land parcel. In particular, topography and shape descriptions were included. The following structure was applied when describing the physical parameters: pcflt $=$ Physical condition
- Flat; pcslop = Physical condition - Sloped; pcdslop $=$ Physical condition - Deeply sloped; regshp = Shape of the land - Regular; irrshp = Shape of the land - Irregular; trishp = Shape of the land - Triangular

\section{Model 03:}

$$
\text { Nominal value }=f\left(\begin{array}{c}
\text { Distance to city center, Zoning law, Archeological law, Access (carpeted, } \\
\text { tarred, footpath, gravel, indirect })
\end{array}\right)
$$

The third estimation added access parameters to the base model. These included the nature and quality of access to the land unit. The following descriptors were included in the model: brdacc $=$ Indirect access; fpacc $=$ Footpath access; carpt $=$ Carpet road access; $\operatorname{tar}=$ Tar road access; concrt $=$ Concrete access road; grvl $=$ Gravel access road

\section{Model 04 (model 3 with the real value of land as the dependent variable)}

Value adjusted for inflation

$$
=f\left(\begin{array}{c}
\text { Distance to city center, } \text { Zoning law, Archeological law, Access (carpeted, } \\
\text { tarred, footpath, gravel, indirect) })
\end{array}\right)
$$


The fourth estimation was the same as the third model in the explanatory variables, but the dependent variable in this case was converted to real value using an inflation adjustment (we used 2000 as the base year for the inflation correction). The reason to repeat the third model only for the real value explanation was the high explanatory power of the third model over the second model. We used stepwise regressions to avoid multicolinearity in land unit specific variables that could emerge if an unrestricted model was used instead of step-wise regressions.

\section{RESULTS AND DISCUSSION}

First, we investigated the trend of land values in KMC area since 1980 based on the valuation of the randomly selected sample separated by commercial and residential land use type and disaggregated by location (figure 2 and 3 ). Such a disaggregated trend analysis is useful for screening for structural breaks in the series of price that were location-specific.

If there were location specific structural breaks, the linear estimation would have had to accommodate such breaks specifically in the estimation. However, based on the trend analysis, we did not observe any structural anomalies for any location in either of two land categories.

Further we noticed that, except in the immediate vicinity of the city centre, in all other locations, the residential land values were escalating at a faster rate than commercial land. This is a key observation for Kandy which is relatively land-locked due to the geography of a valley.

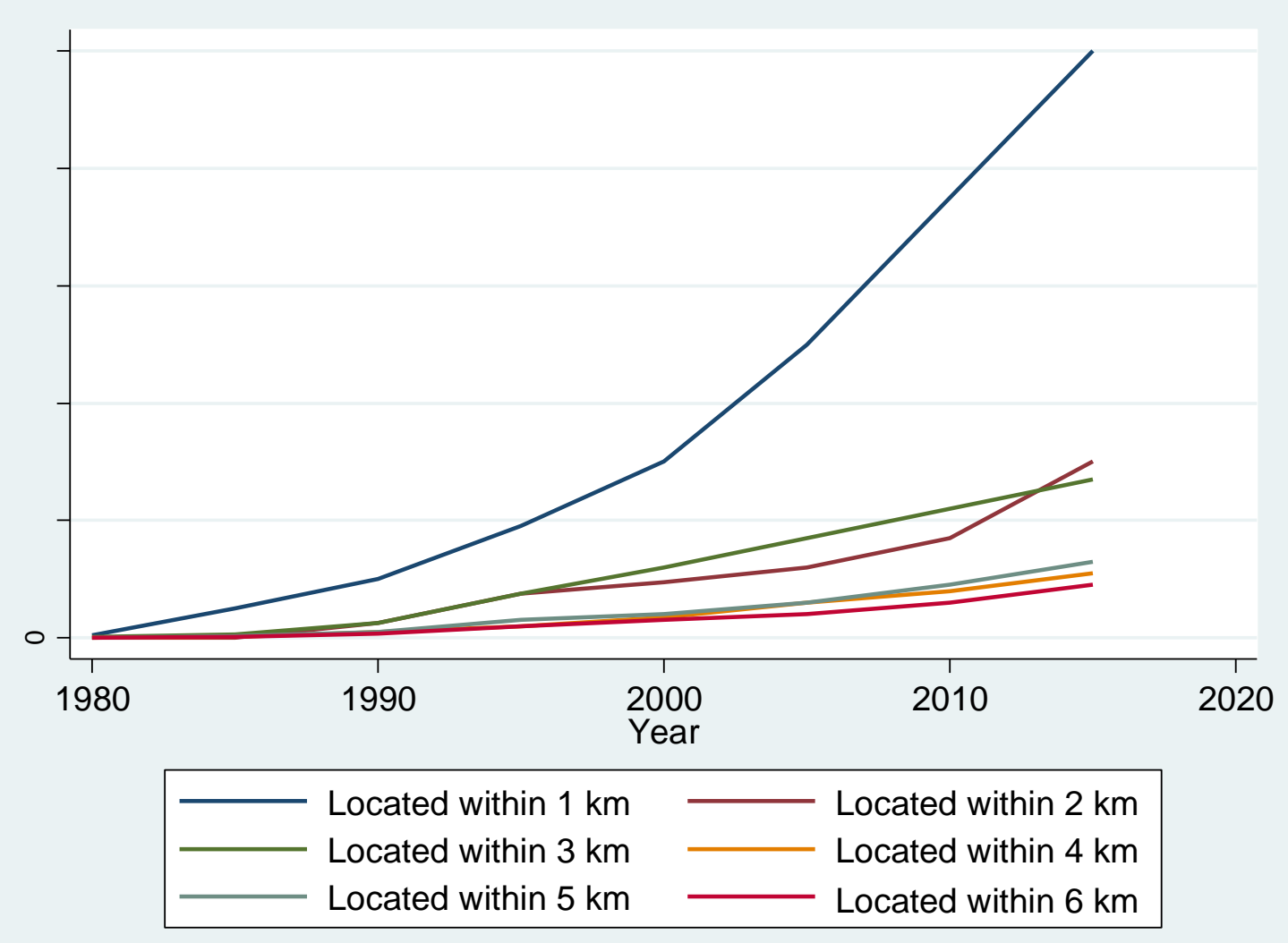

Figure 2. Trend of land values since 1980 - Commercial lands 


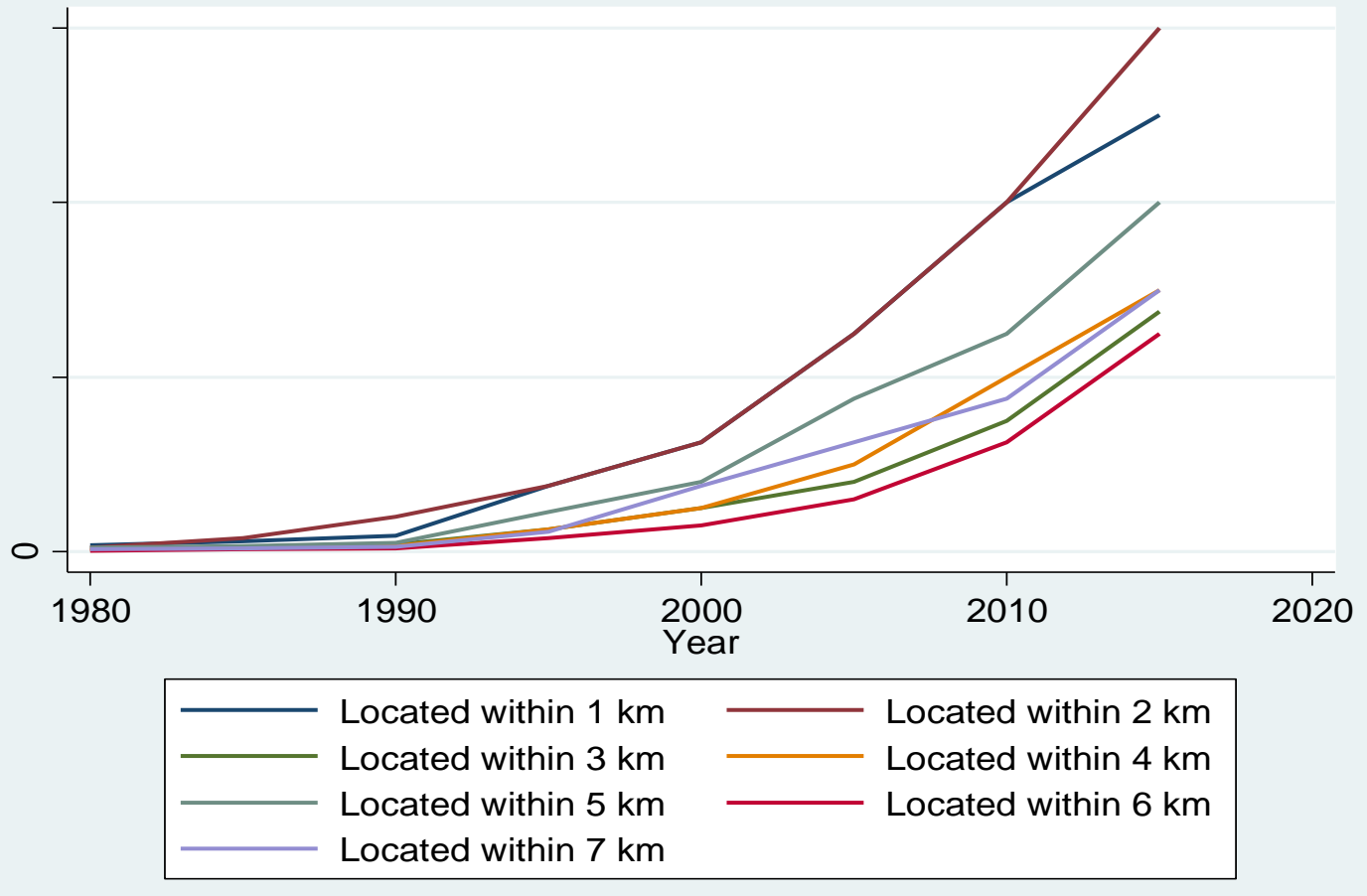

Figure 3. Trend of land values since 1980 - Residential lands

After the trend analysis, the analytical models were estimated. As was highlighted in the introduction, we were interested in two aspects: the identification of significant factors affecting land value and the incremental contribution of such factors on value. The models were compared using the McFadden R squared indicator applicable for stepwise regression approach that we followed in this study. The estimates of parameters are presented in Table 1 to 4 , based on models outlined in the methods. Model 01 reported an adjusted R-square of 0.40 . Variables significant at $99 \%$ confidence included location within 1 to $3 \mathrm{~km}$ and subject to zoning law. However, a positive impact of location on value was observable only for the location category between 0 and $1 \mathrm{~km}$ from city centre. The impact of archaeological regulation on land values was significant at $90 \%$ confidence level. As per the incremental impact of zoning law, the land value per perch increased by Rs. $1,085,075 /-$ and the land value displayed an increase of Rs. $322,419.90$ with respect to archaeological regulation.

In the second model (table 2), the adjusted $\mathrm{R}$-squared value was 0.42 . In this model, location within 1 to $3 \mathrm{~km}$, and impact of zoning law were significant at 99\% confidence level while location between 0 to $1 \mathrm{~km}$, location between 3 to $4 \mathrm{~km}$ and deeply sloped lands were significant at 95\% confidence level. A positive impact of location was observed only in the category between 0 and $1 \mathrm{~km}$ from city centre. Furthermore, lands located within 5 to $7 \mathrm{~km}$, archaeological regulations, and physical condition as flat \& slopped land, irregular shape were insignificant. This model also showed that the land value per perch increased when zoning law was implemented. The impact of archaeological regulations became insignificant by a small margin of confidence, even though the magnitude of impact was positive. 
Table 1. Statistical significance of location and regulatory factors on land values (Model 01)

\begin{tabular}{lll}
\hline \multicolumn{1}{c}{ Variable } & \multicolumn{1}{c}{$\begin{array}{c}\text { Coefficient } \\
(\mathbf{X 1 0})\end{array}$} & p values \\
\hline Land value - Dependent variable & \multicolumn{1}{c}{} \\
Location within 0-1 km from town centre & 10.42 & $0.001^{* * *}$ \\
Location within 1-2 km from town centre & -113.01 & $0.000^{* * *}$ \\
Location within 2-3 km from town centre & -78.51 & $0.000^{* * *}$ \\
Location within 3-4 km from town centre & -53.75 & 0.134 \\
Location within 4-5km from town centre & -26.60 & 0.567 \\
Location within 5-6 km from town centre & 6.80 & 0.907 \\
Location within 6-7km from town centre & 33.48 & 0.618 \\
UDA regulations - Zoning law & 108.50 & $0.000^{* * *}$ \\
UDA regulations-Archaeological regulation & 32.24 & $0.065^{*}$ \\
Constant term & 163.14 & $0.000^{* * *}$ \\
\hline
\end{tabular}

Adjusted R-squared 0.4064; Number of observations 1352.

* Significant at $10 \%,{ }^{* *}$ Significant at 5\%,*** Significant at $1 \%$

Table 2. Significance of factors after inclusion of physical characteristics (Model 02)

\begin{tabular}{lll}
\hline Variable & \multicolumn{1}{c}{$\begin{array}{c}\text { Coefficient } \\
(\mathbf{X 1 0})\end{array}$} & p values \\
\hline Land value - Dependent variable & & \\
Location within 0-1 km from town centre & 7.0414 & $0.024^{* *}$ \\
Location within 1-2 km from town centre & -106.09 & $0.000^{* * *}$ \\
Location within 2-3 km from town centre & -88.17 & $0.000^{* * *}$ \\
Location within 3-4 km from town centre & -80.27 & $0.030^{* *}$ \\
Location within 4-5km from town centre & -53.51 & 0.268 \\
Location within 5-6 km from town centre & -17.27 & 0.773 \\
Location within 6-7km from town centre & -23.53 & 0.734 \\
UDA regulations - Zoning law & 108.65 & $0.000^{* * *}$ \\
UDA regulations - Archaeological regulation & 27.39 & 0.115 \\
Physical condition - Flat & 22.43 & 0.254 \\
Physical condition - Sloped & -2.40 & 0.906 \\
Physical condition - Deeply sloped & -39.71 & $0.023^{* *}$ \\
Shape of the land - Irregular & 2.76 & 0.880 \\
Constant & 98.07 & $0.001^{* * *}$ \\
\hline
\end{tabular}

Adjusted R-squared 0.4254, Number of observations 1352

* Significant at $10 \%,{ }^{* *}$ Significant at 5\%, ${ }^{* *}$ Significant at $1 \%$; 
The third model added the access parameters to the base model. It reported an improved adjusted R-squared value of 0.51 . An important point observed here was that, when access parameters were included, the positive impact of location disappeared. This implied that in KMC, it was not really the distance from city centre but the quality of access that increased the land value. Our key variable of interest, the zoning regulation's impact was robustly positive in this specification also. Among the access related variables, only carpet road access was positively associated with value of the land parcel. Other access types were largely negatively associated with land value.

Table 3. Significance of factors after inclusion of access characteristics (Model 03)

\begin{tabular}{lll}
\hline Variable & \multicolumn{1}{c}{$\begin{array}{c}\text { Coefficient } \\
\left(\mathbf{X 1 0}^{4}\right)\end{array}$} & p values \\
\hline Land value - Dependent variable & \multicolumn{1}{c}{} \\
Location within 0-1 km from town centre & -1.60 & 0.606 \\
Location within 1-2 km from town centre & -116.23 & $0.000^{* * *}$ \\
Location within 2-3 km from town centre & -86.49 & $0.000^{* * *}$ \\
Location within 3-4 km from town centre & -69.48 & $0.035^{* *}$ \\
Location within 4-5km from town centre & -25.55 & 0.550 \\
Location within 5-6 km from town centre & -7.22 & 0.893 \\
Location within 6-7km from town centre & 24.64 & 0.689 \\
Zoning law & 45.51 & $0.000^{* * *}$ \\
Archaeological regulation & 22.11 & 0.166 \\
Indirect access & -39.01 & $0.000^{* * *}$ \\
Footpath access & -56.61 & $0.000^{* * *}$ \\
Carpet road access & 119.28 & $0.000^{* * *}$ \\
Tar road access & 5.43 & 0.687 \\
Constant & 191.46 & $0.000^{* * *}$ \\
\hline Adjusted R-squared $\quad 0.5124 ;$ Number of observations & 1352 & \\
* Significant at 10\%, ${ }^{* *}$ Significant at 5\%,** Significant at $1 \%$ & \\
\hline
\end{tabular}

The fourth specification (table 4) estimated the connection of 'real' value of land to the predictors identified in model 3 . We reused the predictors in model 3 as it was the better fitting model. We could observe that the outcomes were same as in model 03. In particular, we noticed that, for inflation- adjusted land value, the positive impact of zoning regulations and carpet access were significantly larger compared to nominal value impacts. This implied that these two factors behave as long-term predictors of land value in KMC area. 
Table 4. Explanation of inflation-adjusted values (Model 04)

\begin{tabular}{lll}
\hline Variable & $\begin{array}{c}\text { Coefficient } \\
\left(\mathbf{X 1 0}^{4}\right)\end{array}$ & p values \\
\hline Real value of Land - Dependent variable & & \\
Location within 0-1 km from town centre & -10.25 & 0.618 \\
Location within 1-2 km from town centre & -472.02 & $0.000^{* * *}$ \\
Location within 2-3 km from town centre & -347.16 & $0.011^{* *}$ \\
Location within 3-4 km from town centre & -267.03 & 0.219 \\
Location within 4-5km from town centre & -59.77 & 0.832 \\
Location within 5-6 km from town centre & 31.68 & 0.928 \\
Location within 6-7km from town centre & 173.86 & 0.669 \\
Zoning law & 289.30 & $0.000^{* * *}$ \\
Archaeological regulation & 122.27 & 0.246 \\
indirect access & -117.95 & $0.012^{* *}$ \\
Footpath access & -202.32 & $0.033^{* *}$ \\
Carpet road access & 729.46 & $0.000^{* * *}$ \\
Tar road access & -32.84 & 0.712 \\
Constant & 709.63 & $0.000^{* * *}$ \\
\hline
\end{tabular}

Adjusted R-squared 0.3953 ; Number of observations 1352;

* Significant at $10 \%,{ }^{* *}$ Significant at $5 \%,{ }^{* * *}$ Significant at $1 \%$

Many studies have found that land-use regulations have significant effects on property values. In many cases, the net effects of regulations were positive, while in other instances there were no effects or negative effects (Runge et al., 1996). Our results, which showed an increase of market value for lands under planning regulations, were consistent with majority of findings in the literature.

Kandy municipality area is a highly demanded area for commercial and residential sites and displayed scarcitydriven prices (more than amenity-driven prices). Therefore, generalizing the results obtained in a study like the present one to other areas of the country is not recommended. On the other hand, our results showed that city planning has positive impacts on land prices. This finding was robust to several model specifications. In a country like Sri Lanka, where many urban and sub-urban areas are not planned adequately, our findings highlight that the market will respond positively to organized planning efforts. One limitation of the present study may be the consideration of only one class of planning regulations, that of Urban Development Authority Law which is applicable only to the urban areas. The current development trajectory in the country expands urban infrastructure into many spaces which are not identified under the above law.

\section{CONCLUSION}

Kandy municipal area presents an interesting case of land value escalation in Sri Lanka. Due to topographical limitations specific to Kandy and the high resident population density, KMC displays residential land values escalating faster than commercial land values in all locations outside $1 \mathrm{~km}$ radius from city centre. 
There were many factors that affect land values in urban areas such as topographic, economic, and demographic dimensions. In addition, land use regulations had significant impacts on land values. Considering the four specifications of hedonic type models, this study found robust statistical evidence supporting a positive impact of zoning regulation on land values irrespective of distance from the city centre.

Development Plan for Urban Development Area of Kandy was gazetted to be in force with effect from April 2002, specifying the land use zoning of the area. While the actual zoning limitations have not come to effect yet, new or further developments are subject to these regulations. Both urban development regulations and the Kandy development plan gave prominence to zoning and archaeological regulations.

\section{REFERENCES}

Asabere, P.C. and Colwell, M.A. (1984). Zoning and the value of urban land. Real Estate Issues, 8(1), 22-27.

Cheshire, P. and Sheppard, S. (1995). On the price of land and the value of amenities. Economics, 62(1), 247-267.

Cheshire, P.C. and Vermeulen, W. (2009). 'Land markets and their regulation: The welfare economics of planning', In: H.S. Geyer (ed) International Handbook of Urban Policy, Vol 2: Issues in the Developed World, Cheltenham: Edward Elgar, 120-151.

El-Barmelgy, M.M., Shalaby, A.M., Nassar, U.A. and Ali, S.M. (2014). Economic land use theory and land value in value model. International Journal of Economics and Statistics. 2, 2014, 91-98.

GOSL (2001). Gazette Extra-Ordinary No. 1209/19 dated 8th November, 2001.

Ihlanfeldt, K.R. (2007). The effect of land use regulation on housing and land prices.
Zoning regulations were the most influential factor related to the land prices and had a strong positive effect. Archaeological regulations also had a positive impact which is lesser in magnitude and not statistically significant within certain models. Overall, we found that zoning regulations and archaeological regulations influenced land values irrespective of the location (i.e. distance from the city centre).

\section{ACKNOWLEDGEMENT}

First author acknowledges the support of the following individuals: R.G. Wimalasena, P.G.I. Wimalaweera, Dickson Bandara, I. Gunasekara, Chief Engineer (Building) and the staff of Kandy Municipal Council and Chief Engineer and the staff of Road Development Authority, Kandy.

Journal of Urban Economics. 61(3), 420-435.

Jaeger, W.K. (2006). The effects of land use regulations on property values. Environmental Law, 26(1), 105-130.

Jimoh, D.A. and Ige, V.O. (2017). Public Infrastructure vs. Residential property rental value in Lagos, Nigeria. Journal of Sustainable Development Studies, 10(1), 17-33.

Kok, N., Monkkonen, P. and Quigley, J.M. (2014). Land use regulations and the value of land and housing: An intrametropolitan analysis. Journal of Urban Economics, 81, 136-148.

Kolowe, P. (2014). The determinants of urban land and property values: The case of Rwanda. Master's Theses. 87. https://repository.usfca.edu/thes/87.

McMillen, D.P. and McDonald, J.F. (1993). Could zoning have increased land values in Chicago? Journal of Urban Economics, 33(1), 197-188. 
Nicholls, S. (2004). Measuring the impact of parks on property values: new research shows that green spaces increase the value of nearby housing. Parks and Recreation, 39(3), 24-32.

Okokor, S.I. (2005). Correlates of urban land values and urban planning regions of BeninCity. Journal of the Nigeria Institute of Town Planners, XVIII (1), 121-141.

Quigley, J.M. and Rosenthal, L.A. (2005). The effects of land use regulation on the price of housing: What do we know?
What can we Learn? Cityscape: A Journal of Policy Development and Research, 8(1), 69-137

Runge, C.F. (2006). Agricultural economics: A brief intellectual history. Centre for International Food and Agricultural Policy Working Paper WP06-1 (St Paul: University of Minnesota Press).

Urban Development Authority (UDA) (2002). Development Plan for Urban Development Area of Kandy, Volume I \& II. UDA Kandy regional office. 